\title{
Analysis of prevention for disease of Sundarbans
}

\author{
Awal Mohd Abdul \\ Environmental Scientist (Ministry of Environment and Forest), Founder \& Chief Advisor, Health \& Pollution Research Farm, Present \\ Address: 23-09-37 Ave, Long Island City, New York, USA
}

\author{
Email address: \\ abdul_awal2004@yahoo.com
}

\section{To cite this article:}

Awal, Mohd Abdul. Analysis of Prevention for Disease of Sundarbans. European Journal of Preventive Medicine.

Vol. 2, No. 4, 2014, pp. 52-62. doi: 10.11648/j.ejpm.20140204.13

\begin{abstract}
Sundarbans is the largest single mangrove forest in the world, occupying about $6,029 \mathrm{~km}^{2}$ in Bangladesh and the rest in India (Iftekhar \& Islam, 2004). The Sundarbans supports a diverse fauna and flora (e.g. Prain, 1903; Siddiqi et al., 1993, Iftekhar, 2006), approximately one million people of Bangladesh and India depend on it directly for their livelihood (Iftekhar \& Islam, 2004), and also it provides a critical natural habitat which helps protect the low lying country and its population from natural catastrophes such as cyclones (e.g. Blasco et al., 1992; Iftekhar, 2008). Despite this designation, this natural forest resources (Sundarbans) in Bangladesh has been facing tremendous problems, including that of dieback (top-dying), human destructions, deforestations, illicit fellings, miss-management of the main tree species (Heritiera fomes) which is affecting millions of trees. The cause of this dieback is still not well understood unknown. The present work has investigated one of the possible factors that might be causing this top-dying, namely the concentrations of various chemical elements present in the sediments, particularly heavy metals, though other chemical parameters such as the $\mathrm{pH}$, salinity, moisture content of the sediment and nutrient status were also assessed. Tree height and trunk diameter were determined as indications of tree growth, counts of seedlings and saplings were made to assess regeneration success, and the intensity of top-dying within the sampled plots was recorded on a rank scale. However, the present results have showed that $\mathrm{Sn}$, Exchangeable $\mathrm{K}$, soil $\mathrm{pH}, \mathrm{Pb}, \mathrm{Zn}$ and $\mathrm{Ni}$ could be directly linked with top-dying disease of Heritiera fomes (Sundri) in Sundarbans, probably particularly by weakening the vigor of the trees and people and allowing other factors such as pathological agents to attack the plants and surrounding people in Sundarbans, Bangladesh (Awal, 2014). In fact, from since then and still now, the natural resource of Bangladesh like Sundarbans is being disturbed ecologically by human destruction.
\end{abstract}

Keywords: Chemical Contamination, Abnormal Elemental Concentration, Health Problems, Causal Factors, Heavy Metal Concentrations, Prevention Of Diseases, Pollution, Natural Resources Degradations, Sundarbans, Top-Dying

\section{Introduction}

Bangladesh is literally a treasure-trove of rich and variegated natural beauty interspersed with enchanting landscape, mighty meandering rivers, exotic flora and fauna, picturesque resorts, long sunny beaches, tropical natural mangrove forests, fascinating art and architecture, ancient relics and archaeological sites and colorful tribal life. As a vacation land, Bangladesh has many facets like Sundarbans natural forest resources in Bangladesh Mosaic of Bangladesh; 2006; External Publicity Wing; Ministry of Foreign Affairs; Government of the People's Republic of Bangladesh; $\mathrm{p}$ : 1-145).

It is a land of enormous economic potentials, inhabited by diligent and hard-working people who have a love for heritage. All of these together make Sundarbans a colorful mosaic of nature's splendor and bounty (Awal, 2007, 2009, 2014).

\subsection{Sundarbans in Bangladesh}

Coastal belt of Bangladesh has been described as a new state in an ancient land. Bangladesh contains greater biodiversity than that of many countries taken together. Indeed few countries in the world can match its rich and varied flora and fauna, which are not only a unique biological phenomenon but are also a great natural resource of the country. The economy is mainly agrarian. Bangladesh is a land of splendor and natural grace-a veritable mosaic in 
green nature, verdant and boisterous, with its dedicated and creative people adding color and vibrancy to its being.

However, three major match factories, two in Khulna and one in Dhaka, depend fully or partly on the Sundarbans for their raw materials, and the total daily requirement of wood for these three factories is 320 tons (Anon, 1986). The Khulna hardboard mill uses entirely Sundri (Heritiera fomes Buch-Ham) of about 5-15 cm in diameter and 1-3 m in length, and the mill's annual requirement for raw material varies from 19,000 to 28,000 cubic meters stacked volume (Anon, 1986). Several forest based industries in Khulna also depend entirely on the Sundarbans (Anon, 1986). The quantities of minor forest produce from the Sundarbans during 1982-83 were Golpatta (Nipa fruiticans wurmb), 62,000 tons, honey 232 tons, beeswax 58 tons, and shells 2,200 tons (Chaffey, et al., 1985); and Islam (1993) reported $80,000 \mathrm{~kg}$ of beewax being harvested annually.

History records that till the advent of the British in the eighteenth century; Bangladesh had an enviable position in the entire region and was known as the legendary land of affluence and prosperity. The country has almost achieved green revolution. Sub-sectors like fishery, livestock rearing, and forestry are growing by leaps and bounds. The Bay of Bengal is literally a treasure- trove of sea fish and other wealth. Bangladesh's major natural forest resource is Sundarbans (figure1). There is also bright prospect of striking oil and gas. Huge deposits of coal, limestone, peat, bitumen, hard rock, lignite's, white clay etc. have already been indentified and projects are being implemented for their harnessing for productive use(Mosaic of Bangladesh; 2006; External Publicity Wing; Ministry of Foreign Affairs; Government of the People's Republic of Bangladesh; p:1145).

\subsection{Direct Destruction of Sundarbans}

Mangroves in Asia including Bangladesh, India, and East Africa previously contained a much fuller range of species (Seidensticker, and Hai, 1983; Khan, 1997). In the Southeast Asian region, species diversity of mangroves was previously much higher, where approximately two-thirds of all species and $70 \%$ of the major vegetation types with $15 \%$ of terrestrial species in the Bangladesh-India-Malayan realm have already been destroyed (Ellison, 1998, 2000). The Indo-Pacific region is known for its luxuriant mangroves. The mangrove zone of Bangladesh is about 710 $\mathrm{km}$ long including several tiny islands (Rahman, et al., 2003). In the present day the Indo-Malayan mangroves are confined to Sundarban reserved forests, mainly in Bangladesh.

Coastal lands cover $6 \%$ of the world's land surface (Tiner, 1984). Coastal and wetlands everywhere are under threat from agricultural intensification, pollution, major engineering schemes and urban development, (UN-ESCAP 1987; 1988). According to Miller et al. (1985, 1981), this forest had been affected by direct human destructions, human settlement and agricultural activities during and under both the Bengal Sultanate (1204-1575) and the
Mughal Empire (1575-1765). At the arrival of British rule in 1765 , the Sundarbans forests were double their present size and significant exhaustion of the growing stock led to dwindling by $40 \%$ - 45\% between 1959 and 1983 (Chaffey et al., 1985).

\subsection{Severity of Destruction in Sundarbans Natural Resources}

The Sundarbans provide critical habitat for a diverse marine and terrestrial flora and fauna, and 3.5 million people depend on Sundarbans forests and waterways for their survival (Anon, 1986; Chaffey et al, 1985). But, Bangladesh is the one of the most densely populated countries (World Fact book, July 2006). Bangladesh is facing many problems including environmental pollution, high population density and poverty, these problems being interlinked with each other. These unique coastal tropical forests are among the most threatened habitats in the world. They may be disappearing more quickly than inland tropical rainforests, and so far, with little public notice. Enrichment and illicit removal of timber and firewood from the forests are the major forest conservation problems in Sundarbans. Approximately 2.5 million people live in small villages surrounding the Sundarbans, while number of people within $20 \mathrm{~km}$ of the Sundarban boundary was 3.14 million (Islam, 1993). The total forest area of Bangladesh is about 2.47 million ha, which accounts for about $18 \%$ of the total land area of the country, and which constitutes $0.15 \%$ of the world's total tropical forests (Haque, 2000), although an estimate from 1993 only put the tree cover at $5-7 \%$ of the country's area (FAO,1993). Sundarbans comprises $45 \%$ of the total productive forests in Bangladesh, and contributes about $50 \%$ of forest related revenue. The 1993 total wood supply in the country was 6.2 million $\mathrm{m}^{3}$ against a demand of 8.34 million $\mathrm{m}^{3}$, with a sustainable local supply for only 1.3 million $\mathrm{m}^{3}$. Sixty five percent of forest products are consumed as fuel wood (GOB, 1993). The annual average destruction of forest land in the country was 8000 ha in 1980 and subsequently it increased to 38000 ha in 1981-90 according to FAO (1993). But probably the rate of destruction of forest is more severe than the official statistics as it is very difficult to estimate the real picture (Awal, 2007\}. Deforestation affects one eighth of the country's land areas (Awal, 2007). Approximately 100,000 to 200,000 people work inside the Sundarbans for at least 6 months, while the number of people entering the forest in a year could be as high as 3,000,000 (Hussain and Karim, 1994). Of these, about 25,000 people work in fish drying and 60,000 - 90,000 people in shrimp post-larvae collection inside the Sundarbans (FAO, 1994). About one million people are engaged in shrimp larval collection in the rivers and creeks around the outside of the Sundarbans (Chantarasri, 1994).

The Sundarbans, like other tidal forests, is tolerant of natural disturbances such as the cyclones and tidal waves of the Bay of Bangle, but it is highly vulnerable to human disturbances (Seidensticker, 1983). Most of the abuses 
found in professional forestry management elsewhere have been observed here as well, such as excessive cutting of stocks in the auctioned area and connivance between purchasers and forestry staff to cut wider areas than sanctioned (Bari, 1993).

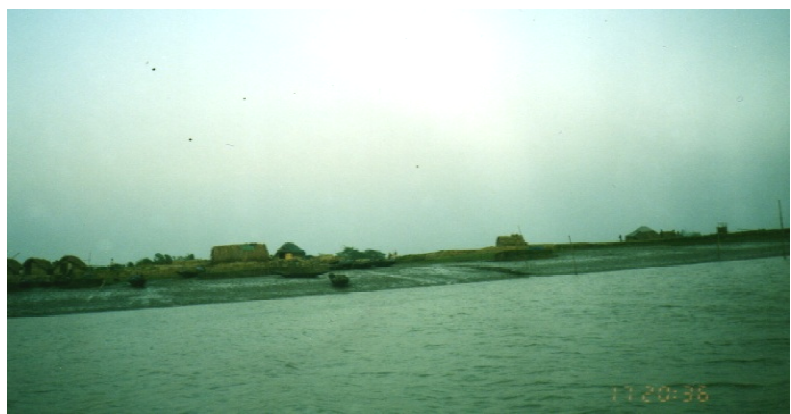

Figure 2.0. Photograph of part of the Sundarbans coastal area, near compartment number 26, where the trees have been cut down to be replaced by a fishing village.

The major usable forest species include a wide variety of mangroves, and government auction of trees such as the gewa, sundri, and nipa palm have brought substantial revenues each year (Bari, 1993). Gewa is the principal supply of raw-material for the Khulna Newsprint Mills, a 48,000-ton facility built in 1959, and a significant (GRPB, 1985) export earner. Much, if not most, of this industry was situated to the east of Sundarbans, but there appeared to be considerable interest in increasing crustacean culture in the reserved forest (GRPB, 1985), an interest doubtless spurred by the Government target for exporting shrimp included in the 1985-90 five-year-Plan (GRPB, 1985). Certainly deterioration in the vegetation is already welldocumented (International Engineering Company, 1980). Besides recent changes in vegetation, geomorphic changes in the Sundarbans environment are also rapid (Personal observation; Faizuddin, 2003). Also, there were 157 major oil spills in tropical seas between 1974 and 1990 (Burns et al., 1993). Deep mud coastal habitats may take 20 years or more to recover from the toxic effects of such oil spills (Phillips, 1994).Some more details on specific threats to the Sundarbans are given in the following sections. It should also be remembered that these factors probably do not only operate singly, but are likely to interact in their effects; however, they have been divided into individual factors for convenience of discussion.

\section{Methodology}

In this section the various field and laboratory methods used in this study will be discussed as below:

\subsection{Field Sampling Methods}

The Sundarbans Reserved Forest is located at the south west corner of the Ganges River Delta close to the Bay of Bengal, mainly on the sea-shore line, river banks, channels, and small creeks. The location of the Sundarbans within Bangladesh has been shown in Figure 2.0.

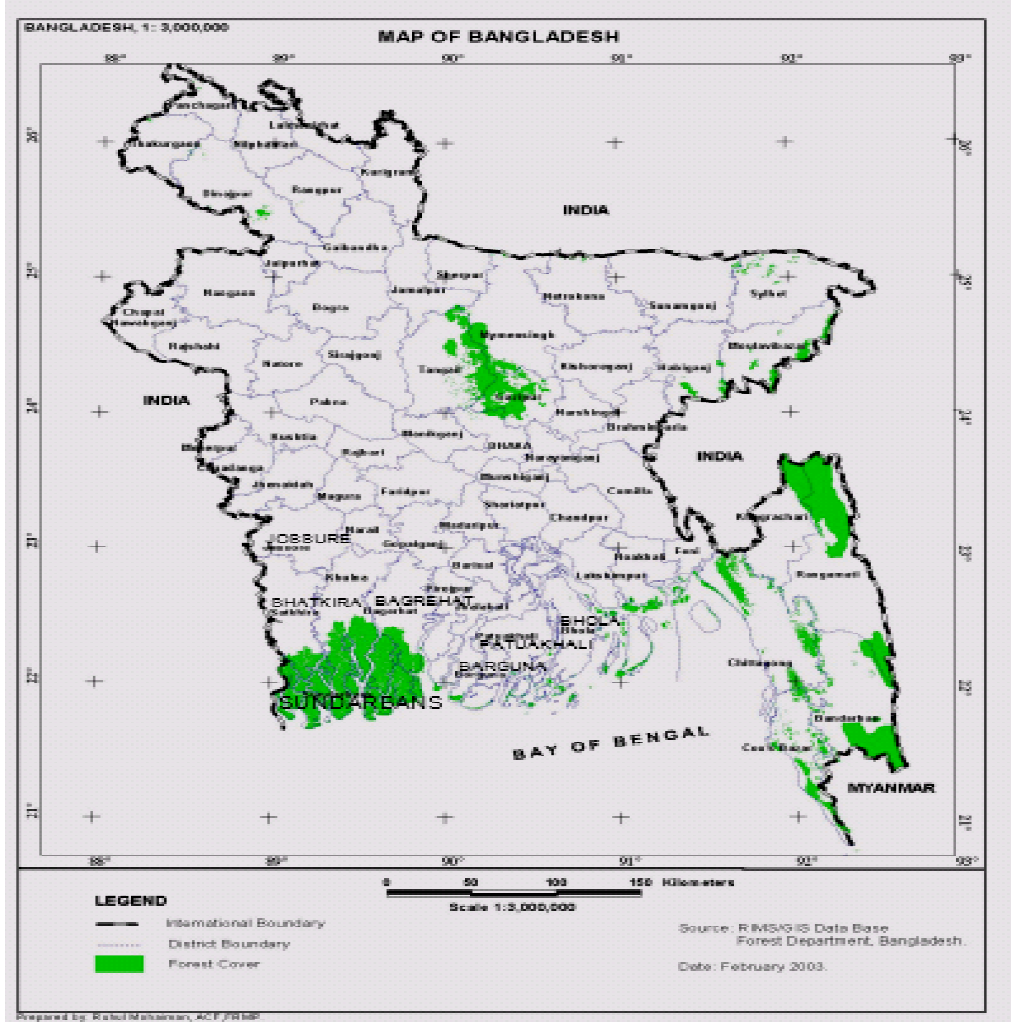

Figure 1.0. Map showing the administrative districts of Bangladesh, including the location of the Sundarbans (the shaded area in the south-west of the country) 


\subsubsection{Site Selection and Location of the Study Area}

General reconnaissance of possible sites was made by visiting all the possible regional areas before categorizing and selecting plots for sampling. It was decided to sample from the Chandpai area which is the mostly human accessible and ecologically polluted area (in Figure 1.0). Three compartments from this regional area (range), namely numbers 26,28 and 31 , were selected because they were believed to represent a range of severity of top-dying disease, based on relevant maps, documents, literature, consultations with forest professionals, and surrounding peoples. The location of these compartments within the Chandpai area, and the location of this area in the wider Sundarbans is shown in Figure 2.0. Among the three compartments, compartment number 26 was selected as an area highly affected by top-dying, where most of the trees were affected severely. Compartment 26 had pronounced human activities, and also in places is undergoing rapid housing development involving extensive construction activities due to the presence nearby of the Range HQ office in Chandpai (in figure 1.0). Compartment number 28 was selected as a moderately affected area. This compartment has various human activities including boat making grounds, football-playing grounds, and cattlegrazing fields, all types of major soil erosion, a moderate amount of construction activities and the presence of communities of fishermen (figure 1.0). Compartment number 31 was chosen as being relatively little affected by top-dying disease.

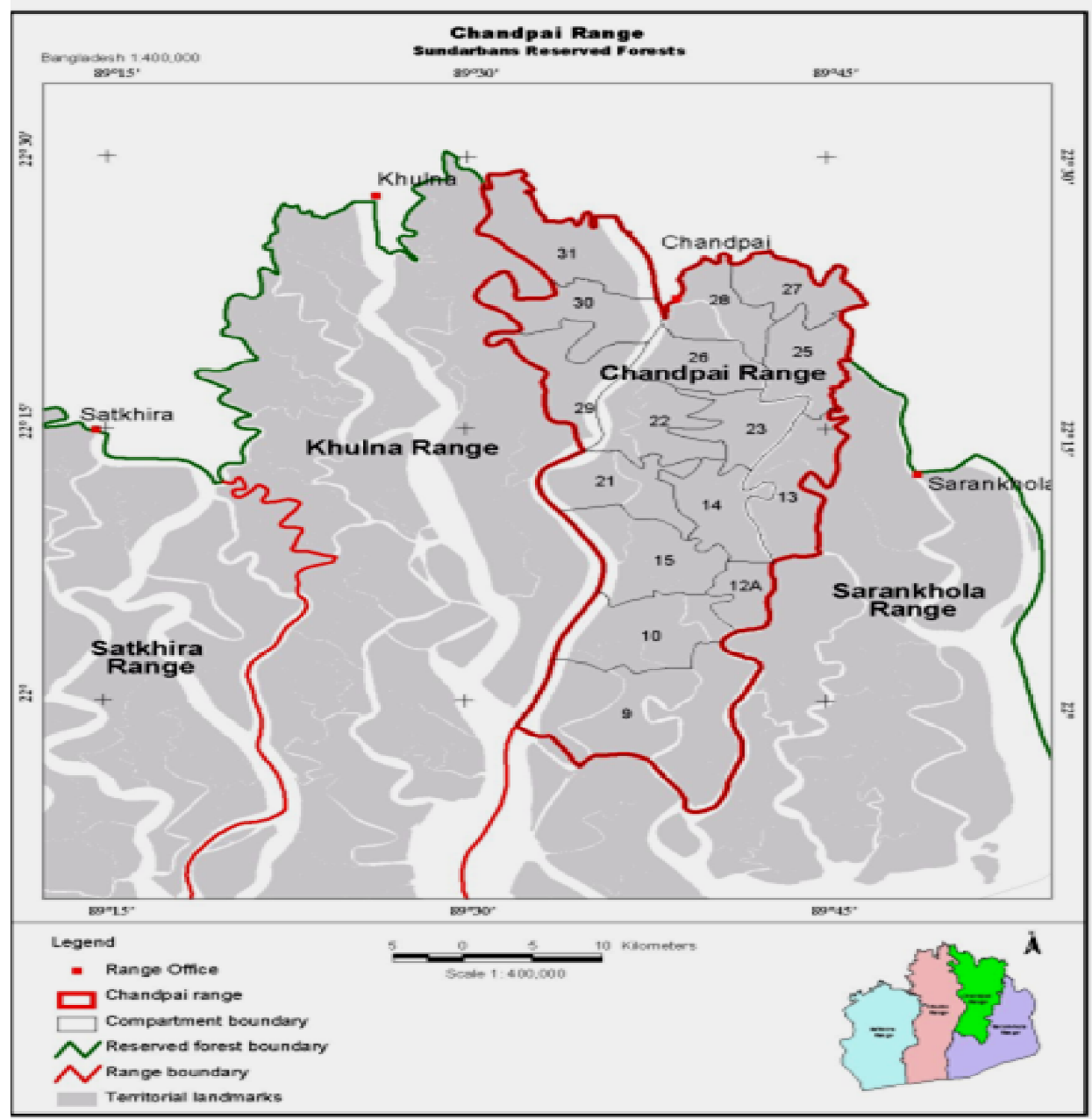

Figure 3.0. Map showing the location of the numbered compartments within the Chandpai area, and the position of this area relative to other parts of the Sundarbans in Bangladesh (darker shaded area).

Of the three chosen compartments (Figure 3), the nearest compartment to Mongla port is compartment 31, with comparatively modest human activities, but which nonetheless involve clear-cutting of natural vegetation, replanting with other species rather than mangrove or other native species, all types of soil erosion, and construction activities present. Within each of the three compartments, detailed observations of the regeneration and sampling of soil and water took place within three $20 \mathrm{~m} \times 20 \mathrm{~m}$ plots, chosen to reflect a range of top-dying intensities (High, medium and Low for that area). The sampling was conducted in a randomized block design, in that a plot was 
sited within a particular top-dying intensity block, but the precise location of that plot was randomized so as not to bias the detailed data collection. Thus in total nine plots were sampled, representing a range of top-dying intensities.

Intensive field data collection was made among these nine selected plots (in Figure 4.0). Observations were performed from observation towers during low and high tides, also traversing the forest floor and vegetation on foot, as well as using a speed boat, trawlers, country-boats, and a launch as required to gain access.

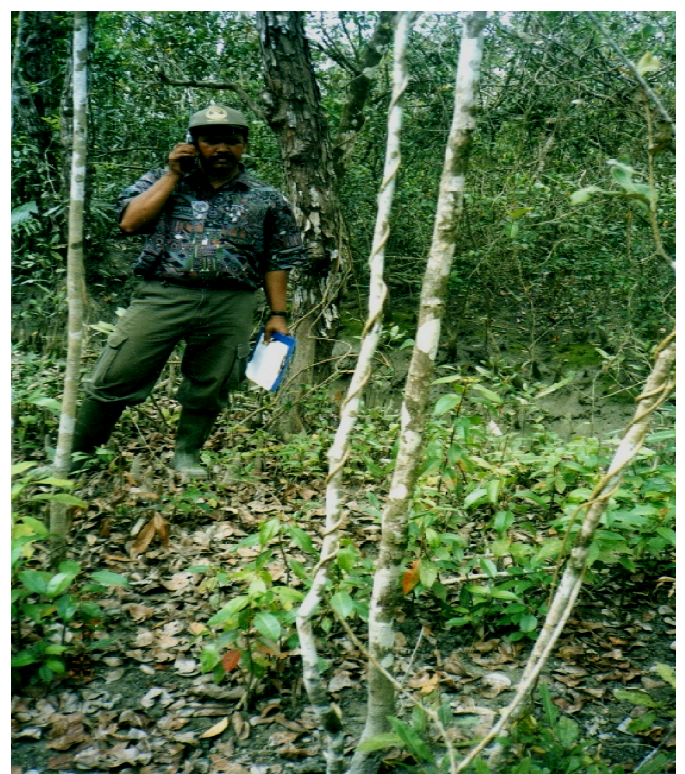

Figure 4.0. Photograph showing the Sundarbans forest trees and understory vegetation. The adult trees behind the author are of Heritiera fomes. The forest floor shows dead leaves from trees affected by top-dying.

All sampling was accompanied by Deputy Rangers, Foresters, and Forest guards armed with a rifle from the local office, Chandpai range, Bangladesh Forest Department, to prevent a fatal attack by a Bengal tiger (Panthera tigris).

Table 1.0. Data on locations of plots, as indicated by Geographical Position System (G.P.S).

\begin{tabular}{|c|c|c|c|}
\hline \multirow{2}{*}{$\begin{array}{l}\text { Compartment } \\
\text { Number. }\end{array}$} & \multirow{2}{*}{$\begin{array}{l}\text { Plot } \\
\text { Number. }\end{array}$} & $\begin{array}{l}\text { Global Position } \\
\text { reading. }\end{array}$ & Systems (GPS) \\
\hline & & North latitudes & East longitudes \\
\hline 26 & 1 & $\mathrm{~N} 22^{\circ} 32^{\prime} .35$ & E $089^{\circ} 64^{\prime} .47$ \\
\hline 26 & 2 & $\mathrm{~N} 22^{\circ} 32^{\prime} .98$ & $\mathrm{E} 089^{\circ} 64^{\prime} .28$ \\
\hline 26 & 3 & $\mathrm{~N} 22^{\circ} 33^{\prime} .82$ & E $089^{\circ} 63^{\prime} .50$ \\
\hline 28 & 4 & $\mathrm{~N} 22^{\circ} 36^{\prime} .73$ & E $089^{\circ} 66^{\prime} .53$ \\
\hline 28 & 5 & $\mathrm{~N} 22^{\circ} 36^{\prime} .38$ & Е $089^{\circ} 66^{\prime} .91$ \\
\hline 28 & 6 & $\mathrm{~N} 22^{\circ} 36^{\prime} .89$ & E $089^{\circ} 66^{\prime} .29$ \\
\hline 31 & 7 & $\mathrm{~N} 22^{\circ} 42^{\prime} .82$ & E $089^{\circ} 57^{\prime} .61$ \\
\hline 31 & 8 & $\mathrm{~N} 22^{\circ} 42^{\prime} .72$ & E $089^{\circ} 58^{\prime} .44$ \\
\hline 31 & 9 & N $22^{\circ} 44^{\prime} 20$ & E $089^{\circ} 58^{\prime} .21$ \\
\hline
\end{tabular}

Fieldwork was performed in October, 2003 to March, 2004. Locations of sampling points were determined using a Global Positioning System with a precision of 5-10 m
(Table1.0). For one typical plot, in compartment 31, the altitude was recorded as $4.4 \mathrm{~m}$ above sea level.

\subsubsection{Vegetation Recording Methods in the Field}

Within each of the nine $20 \mathrm{~m} \times 20 \mathrm{~m}$ plots, each adult tree was assessed for three parameters. The diameter at $1 \mathrm{~m}$ height was recorded (in $\mathrm{cm}$ ) by using a tree diametermeasuring tape or slide callipers depending on girth. The tree height to the top of the crown was determined mainly by ocular estimation but some heights were checked by using Clinometers at a set distance of $20 \mathrm{~m}$ to test the accuracy of such ocular estimations.

Finally, the status of the tree in respect of the amount of top-dying was assessed by using a four point qualitative scale of intensity, namely; not affected, little affected, moderately affected or highly affected by top-dying. This was later expressed as a semi-quantitative or rank scale of 0 to 3 respectively, so that a median rank value could be calculated and used as an index of top-dying intensity in that plot. After that, the total number of seedlings (individuals of the tree species $<1 \mathrm{~m}$ tall), and saplings (young trees $>1 \mathrm{~m}$ tall with a diameter of trunk of $<10 \mathrm{~cm}$ ), were counted within the plots. Care was taken to ensure that trees, saplings and seedlings were not counted more than once or missed in the counting process. After recording, adult trees were marked with white chalk to segregate those marked trees from other trees, seedlings and saplings; red paints were applied to all seedlings and saplings as they were recorded.

\subsubsection{Soil and Water Sampling Methods}

As stated above, from the three selected compartments, a total of nine plots of $20 \mathrm{~m} \times 20 \mathrm{~m}$ were selected. From each of these plots, seven soil samples were collected; one from the centre of the plot, four (one each) from all the corners, and two from the middle sides of the plot. Therefore a total of 63 soil samples were taken. Also nine water samples were collected from nearby rivers, creeks or channels, one from the area of each of the sampled plots. Soil samples were collected from $0-30 \mathrm{~cm}$ soil depth by using a stainless steel spatula and steel cylinder $(d=5.25 \mathrm{~cm})$, and all soil samples were kept in sealed plastic bags. Water samples were collected directly in pre-cleaned plastic-containers. Marking and labelling was performed with a detailed description of the selected sampling site on both the soilcontaining plastic bags and water containers, and preserved in portable coolers until arrival at the laboratory at Dhaka University for initial chemical analysis. This field sampling method followed the W.H.O, U.K, and E.P.A systems of standard laboratory and field sampling principles, rules and regulations. Rainfall for the area during sample collection was not notably different from the respective monthly averages for the Sundarbans of recent years (shown in Table 2.0 for reference); there was no heavy intensity of rainfall within one month before sampling. 
Table 2.0. Showing previous monthly average rainfall data.

\begin{tabular}{|c|c|c|c|c|c|c|}
\hline Year & 1996 & 1997 & 1998 & 1999 & 2000 & 2002 \\
\hline Location & $\begin{array}{l}\text { Mongla } \\
\text { (mm) }\end{array}$ & $\begin{array}{l}\text { Mongla } \\
(\mathrm{mm})\end{array}$ & $\begin{array}{l}\text { Mongla } \\
\text { (mm) }\end{array}$ & $\begin{array}{l}\text { Mongla } \\
(\mathrm{mm})\end{array}$ & $\begin{array}{l}\text { Mongla } \\
\text { (mm) }\end{array}$ & $\begin{array}{l}\text { Mongla } \\
(\mathrm{mm})\end{array}$ \\
\hline January & 2 & 19 & 29 & 1 & 24 & 13 \\
\hline February & 25 & 35 & 65 & 0 & 9 & 5 \\
\hline March & 24 & 102 & 149 & 0 & 15 & 32 \\
\hline April & 89 & 94 & 91 & 25 & 134 & 74 \\
\hline May & 119 & 241 & 234 & 202 & 288 & 206 \\
\hline June & 453 & 204 & 229 & 262 & 309 & 952 \\
\hline July & 385 & 486 & 304 & 435 & 356 & 389 \\
\hline August & 357 & 422 & 471 & 466 & 209 & 441 \\
\hline September & 133 & 334 & 553 & 568 & 327 & 492 \\
\hline October & 274 & 40 & 110 & 321 & 224 & 62 \\
\hline November & 1 & 4 & 207 & 12 & 5 & 89 \\
\hline December & 25 & 13 & 0 & 0 & 0 & 0 \\
\hline
\end{tabular}

Any evidence of changes was recorded, sometimes obtained through asking local people and forestry staff, or from personal observations. In particular, any soil erosion and diversion of the river's position or of new channels and creeks observed during the data collection period were recorded, as were signs of siltation changes.

\subsubsection{Questionnaire Survey of Local People}

In order to establish the views of local people about the incidence and causes of top-dying, a questionnaire was prepared for asking peoples either individually or in groups. This survey was done among people living or working in the 17 Sub-Districts of Sundarbans, making a distinction between those living within and outside of Sundarbans. They were asked whether they had seen the top-dying disease of Heritiera fomes (Sundri) in Sudarbans for a long time, either through living within the Sundarbans or through visiting Sundarbans for their daily work, for their professional work such as forestry officials, for fishing or for collecting wood as wood cutters, for seasonal honey collection, or other purposes. Groups were made up among targeted people in all locations and from all categories mentioned above, based on age, profession, and also for their sharp memory. In this way, 50 questionnaires were filled up through interview, mostly of groups and sometimes of individual people. The justification of selection of people for the questionnaire survey was that the targeted people were familiar with the top-dying problem in Sundarbans, and are related through their professions with Sundarbans directly and indirectly. The questionnaire started by establishing that the respondents were familiar with top-dying, and went on to seek their views and information on what changes they had observed and whether they had noticed possible causes. This was possible because, most of the interviewees are living within the Sundarbans for their daily activities. So, this survey was performed to receive their indigenous response and knowledge towards top dying and its present conditions, and their ideas about what leads to top-dying, as well as questions about tree regeneration and human health in Sundarbans (Awal, 2014).

\subsubsection{Statistical Analysis}

Initial statistical analysis of quantitative data, particularly of the elemental concentrations, consisted of calculation of arithmetic means, standard deviations and standard error values for each variable separately. Data on the severity of top-dying for each tree in a plot, which had been recorded as ' not affected', 'mildly affected', 'moderately affected', and 'highly affected', were converted into a four-point scale (0-3), so that they could be summed and an average (median) could be determined for each plot, thus producing an index based on ranked data. Comparisons of the strength of relationship between two variables were assessed by correlation: the Pearson's product-moment correlation coefficient where both variables were fully quantitative or the Spearman's rank correlation coefficient where the topdying index was one of the variables. In the case of the Spearman's coefficient, the probability of the outcome was determined by using the approximation to a t-statistic appropriate to these tests (Sokal and Rohlf, 1981). Occasionally, a Pearson's correlation coefficient was calculated where top-dying was one of the variables, in order to check on the extent of the difference between the rank and quantitative versions for these data. Data on frequencies of seedlings or saplings in each of the plots and compartments were tested by $\mathrm{x}^{2}$ contingency table analysis to determine whether there was an association between the selected plot type (severely, moderately or little affected by top-dying) and the three chosen compartments. A similar consideration of the different compartments as comprising one factor, and the plot type as a second, was used to test the pattern of elemental concentrations and other variables by a 2 -factor analysis of variance test with replication. This allows an assessment of the significance, not only of the two factors separately but also of the interaction term linking the two factors. It should be noted that the plot type was not a strictly controlled factor, since the three categories of top-dying intensity were relative to each other within any one compartment and might not have been exactly equivalent between the three categories; interpretation of the results from these tests therefore needs to bear this in mind. MINITAB Release 14 Statistical 
Software has been used for windows on CD-ROM, 2004 edition for all data analysis, both statistical and graphical, except for those produced automatically by the Excel package attached to the ICPMS.

\section{Results}

These results are indicated as follows: if one number (all values in ppb) is given it is a mean, otherwise if a range is given they are the minimum and maximum; the number is followed by the type of material from which the data come, with no text indicating it is from sediments (the most common material reported in the literature); finally, the number in brackets indicates the numbered reference source, the sources being indicated in the legend. Besides attempting to establish whether the element concentrations are elevated or not, it is valuable to explore whether there is any marked spatial (as opposed to random) variation in the concentrations found.

Table 3. Mean ( \pm 1 S.E.) and extreme heavy-metal elemental concentrations (ppb) in Sundarbans, together with comparisons with values from other published sources. An asterisk denotes a value below the limits of detection. Comparable data could not be found for all elements.

\begin{tabular}{|c|c|c|c|c|c|}
\hline \multirow[b]{2}{*}{ Element } & \multicolumn{4}{|c|}{ Values from this study } & \multirow{2}{*}{$\begin{array}{l}\text { Values reported elsewhere } \\
\text { (Data refer to sediments unless otherwise stated; number within brackets } \\
\text { indicates source in footnote) }\end{array}$} \\
\hline & Minimum & Mean & S.E. & Maximum & \\
\hline $\mathrm{Al}$ & 0.89 & 16332.44 & 854.17 & 37570.00 & $420-585\left(\right.$ soil $\left.^{1}\right) ; 8089000-46100000\left(^{1}\right) ; 500\left(\right.$ spring and well water, $\left.{ }^{2}\right)$ \\
\hline As & $*$ & 4.56 & 0.24 & 10.06 & $3150-6830\left(^{7}\right)$ \\
\hline B & 0.55 & 19.20 & 2.14 & 103.80 & 2600 (spring and well water, ${ }^{2}$ ) \\
\hline $\mathrm{Ba}$ & 0.59 & 52.41 & 2.37 & 141.80 & $300\left(\right.$ spring and well water, $\left.^{2}\right) ; 141\left(\right.$ coastal soils, $\left.{ }^{5}\right)$ \\
\hline $\mathrm{Bi}$ & $*$ & 0.40 & 0.02 & 0.74 & \\
\hline $\mathrm{Cd}$ & 0.15 & 0.55 & 0.03 & 1.62 & $\begin{array}{l}0.52-0.92\left(\text { soil }^{1}\right) ; 300-13520\left({ }^{1}\right) ; 43-147\left({ }^{4}\right) ; 0.8\left(\text { coastal soils },{ }^{5}\right) ; 11-65 \\
\left({ }^{7}\right)\end{array}$ \\
\hline Co & 5.93 & 31.31 & 5.65 & 143.60 & $\begin{array}{l}0-7.9\left(\text { ocean water, }^{3}\right) ; 3800-26000\left({ }^{1}\right) ; 10.6\left(\text { coastal soils },{ }^{5}\right) ; 5540-15500 \\
\left({ }^{7}\right)\end{array}$ \\
\hline $\mathrm{Cr}$ & 3.11 & 15.72 & 3.39 & 114.90 & $\begin{array}{l}7\left(\text { spring and well water, }{ }^{2}\right) ; 1480-8560\left(^{4}\right) ; 41.2\left(\text { coastal soils, }{ }^{5}\right) ; 12.8 \\
\left(\text { water, }{ }^{6}\right) ; 33200\left(\left(^{6}\right) ; 19500-46100\left(^{7}\right)\right.\end{array}$ \\
\hline $\mathrm{Cu}$ & 1.85 & 10.52 & 1.71 & 43.76 & $\begin{array}{l}\left.12.2-16.6\left(\text { soil }^{1}\right)^{2}\right) ; 12940-85600\left({ }^{1}\right) ; 22\left(\text { spring and well water, }{ }^{2}\right) ; 22-37.2 \\
\left.\left.\left(\text { ocean water, }{ }^{3}\right) ; 2270-14730\left({ }^{4}\right) ; 23.1 \text { (coastal soils, }{ }^{5}\right) ; 3.8 \text { (water, }{ }^{6}\right) ; 18200 \\
\left({ }^{6}\right) ; 6950-31600\left(^{7}\right)\end{array}$ \\
\hline $\mathrm{Fe}$ & 25.82 & 173891.10 & 9883.85 & 248200.00 & $\begin{array}{l}634-820\left(\text { soil }^{1}\right)^{2} ; 8080000-52000000\left({ }^{1}\right) ; 63\left(\text { spring and well water, }{ }^{2}\right) ; 6.2- \\
\left.131.5 \text { (ocean water, }{ }^{3}\right) ; 38.5\left(\text { water, }^{6}\right) ; 7110000\left(^{6}\right)\end{array}$ \\
\hline $\mathrm{Hg}$ & * & 6.41 & 1.47 & 83.30 & $66-180\left({ }^{4}\right) ; 1.8\left(\right.$ water, $\left.{ }^{6}\right) ; 6320\left(^{6}\right)$ \\
\hline $\mathrm{Mn}$ & 0.70 & 436.80 & 14.69 & 697.00 & $\begin{array}{l}\left.4980-438000\left({ }^{1}\right) ; 25 \text { (spring and well water, }{ }^{2}\right) ; 1.8-40.8 \text { (ocean water, }{ }^{3} \text { ); } \\
\left.\left.3738 \text { (coastal soils, }{ }^{5}\right) ; 7.4 \text { (water, }{ }^{6}\right) ; 412000\left({ }^{6}\right)\end{array}$ \\
\hline Mo & 0.20 & 1.62 & 0.46 & 26.15 & 24 (spring and well water, ${ }^{2}$ ) \\
\hline $\mathrm{Ni}$ & 7.58 & 76.08 & 18.84 & 1127.00 & 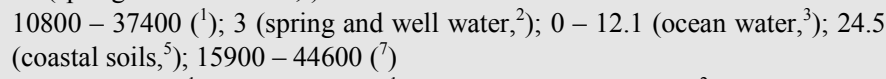 \\
\hline $\mathrm{Pb}$ & 0.32 & 19.30 & 0.98 & 34.19 & 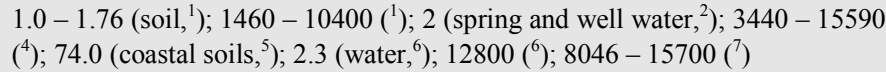 \\
\hline $\mathrm{Rb}$ & 0.18 & 36.37 & 1.65 & 76.94 & \\
\hline $\mathrm{Sb}$ & $*$ & 0.09 & 0.05 & 2.93 & $30-94\left({ }^{7}\right)$ \\
\hline $\mathrm{Sc}$ & $*$ & 6.05 & 0.37 & 8.98 & \\
\hline $\mathrm{Se}$ & * & 0.17 & 0.05 & 1.43 & \\
\hline $\mathrm{Sn}$ & $*$ & 0.61 & 0.16 & 9.68 & $219-654\left(^{7}\right)$ \\
\hline $\mathrm{Sr}$ & 0.18 & 27.77 & 0.89 & 44.17 & 2200 (spring and well water, ${ }^{2}$ ) \\
\hline $\mathrm{Ti}$ & 4.61 & 475.39 & 26.26 & 1350.00 & $72-341\left(^{7}\right)$ \\
\hline $\mathrm{V}$ & 0.09 & 32.93 & 1.14 & 51.65 & 13 (spring and well water, $\left.{ }^{2}\right) ; 18500-46900\left(^{7}\right)$ \\
\hline $\mathrm{Y}$ & 0.03 & 6.60 & 0.34 & 16.69 & \\
\hline $\mathrm{Zn}$ & 2.30 & 73.60 & 2.23 & 112.50 & $\begin{array}{l}\left.35.0-56.2\left(\text { soil }^{1}\right) ; 120-62200\left(^{1}\right) ; 2.4-20\left(\text { ocean water, }{ }^{3}\right) ; 72.5 \text { (water, }{ }^{6}\right) \text {; } \\
43200\left({ }^{6}\right) ; 24300-76000\left(\left(^{7}\right)\right.\end{array}$ \\
\hline
\end{tabular}

${ }^{1}$ Balasubramanian, 1999. ${ }^{2}$ Bond, R G \& Straub, C P (eds), $1973{ }^{3}$ Braganca \& Sanzgiri, 1980. ${ }^{4}$ IUCN Reports $1987 .{ }^{5}$ McGrath \& Loveland (1992). ${ }^{6}$ Sarkar, S.K. et al. 2003 ( Premonsoon data from the mouth of the Ganga estuary near Gangasagar used). ${ }^{7}$ Zöckler, C \& Bunting, G 2006.

\section{Discussion}

Coastal and wetlands everywhere are under threat from agricultural intensification, pollution, major engineering schemes and urban development (UN-ESCAP 1987; 1988). The Indo-Pacific region is known for its luxuriant mangroves. The distribution of mangroves in the Indo-West Pacific bio-geographical region has been outlined in Macnae (1968). However, the mangroves in half of these countries, as well as those of other regions, have since been destroyed through various pollution problems and population pressure (Peters et al., 1985). The country's food security and public health will be in danger if the water and wetlands are destroyed at the present rate (Awal,2009).Unplanned natural resources management and environmental contamination in Sundarbans are fast destroying the surface, vegetation, water, and underground fresh water sources (Awal, 2014). The primary source of fresh water for fishes, trees, human's health in Bangladesh 
was vital but due to heavy-metal contaminations in soil, water, faulty-vegetation management and deforestations of trees, top-dying disease and other diseases and health problems, irrigation for food production, industrialization, and public health, while industrial pollution and poor sanitation are making surface water unusable (Awal, 2007). The health of vegetation including natural flora \& fauna, drinking water, soil are largely depends on uncontaminated groundwater,(Awal, 2009). Water related diseases are responsible for 80 percent of all deaths in the developing world (Awal, 2014).Data were summarized by calculating means and standard errors, and by noting minimum and maximum values, for comparison with other data reported in the literature. The spatial variability in the data was assessed by calculating two-factor analyses of variance with replication, where the factors used were the broadscale variation between compartments, the smaller-scale variation between plots within the same compartment, and the interaction between these two sources of variation. The concentrations of the various trace metals determined by ICP-MS from our Sundarbans soils are given in Table 3. For completeness, the minimum and maximum values are given, as well as the mean and the standard error, in order to facilitate comparisons with other published information and to indicate the extent of variability between the different samples in the results. It is clear that due to destruction of natural resources and contaminations of soil, water for some elements the variability is considerable; for example, nickel has a maximum value many times larger than the mean, while for iron the mean and maximum are more similar but the minimum is substantially smaller.

In order to try and establish whether these values are elevated compared to other data, comparison values are included in Table 2 from results published in the literature concerning the Bay of Bengal region. In order to assess this, an analysis of variance has been performed for each element separately, testing for location by using the compartment from which the samples were taken as one factor, and the plot number within each compartment as a second factor, testing also for interaction between these two sources of variation. The results of these analyses are presented in Table 3, showing only those elements which showed at least one F-value at or near significance. Most of the elements tested do not show any significant variation related to any of these factors, and may therefore be considered to be relatively uniform or non-consistently variable in their concentrations, at least across the compartments studied here. There were no elements that proved significant when comparing between plots, nor in the interaction term, although antimony had a close result for the plot term $(p=0.06)$. However, a few elements did give significant results comparing between compartments, namely bismuth, scandium, strontium and vanadium. In all four cases, the lowest recorded concentrations were from compartment number 28; in all cases except for strontium, the compartment where the highest elemental concentrations were recorded was number 26 (compartment
31 being the highest for strontium). Interestingly, a similar analysis of concentrations (not presented separately here) also showed significant differences between compartments for sodium and phosphorus, with compartment 28 again having the lowest recorded concentrations.

In particular, the metal values from sediments are likely to be much higher than those from soils, and indeed one author (Balasubramanian, reported by Swaminathan, 2000) found sediment values to be often at least one thousand times higher than values for equivalent soils. The concentration values for the various trace metals recorded in Table 3 are believed to be amongst the first published for soils from the Sundarbans, and as such provide baseline data for comparison with other future studies in the area. It has therefore not been possible in many instances to find appropriate comparators from the literature in order to help assess whether the data show elevated concentrations from those expected in such soils. The comparatives information from the literature presented in Table 3.0 is all from the same general region, but includes values from water (from ocean, springs or wells), from coastal soils (but not within the main mangrove areas), and particularly from mangrove sediments, as well as a few from mangrove soils. All comments based on these other sources must therefore be judged on the basis of the differences between the materials in the results likely to be obtained. A further complicating factor in interpreting these results is the high degree of variability in concentrations between different samples shown by many elements, as indicated in Table 3.0 by the high standard error values and by the results highlighted for some elements in Table 3.0.

For most of the elements tabulated there are either no comparisons in the literature, or the results from our study do not appear particularly elevated compared to other results. Perhaps surprisingly, given the problems that have been identified with elevated concentrations of arsenic (As) in groundwater in Bangladesh (e.g. Nickson et al., 1998; Chowdhury et al., 2000), this element was not notably high in the soils studied here. However, there were other metals which may be elevated in their concentrations. Two results appeared particularly elevated, namely those for mercury $(\mathrm{Hg})$ and for nickel $(\mathrm{Ni})$. In considering the result for mercury, it is recognized that the ICP-MS method of testing the soils is not the most appropriate one for obtaining an accurate determination of mercury concentration because of the potential for cross-contamination of samples from earlier ones due to retention of the element within the instrument. The problem was reduced by the use of goldwash solution rather than nitric acid in preparation of the calibration standards. Nonetheless, the elevated concentrations of mercury in these mangrove soils can only be considered as an indication until confirmation of these values by further work involving a different analytical procedure can be completed.

There is likely to be considerable geographic variation in the extent of pollution problems in the different parts of the Sundarbans, associated both with the proximity to local 
polluting sources such as Mongla port and with the extent to which the area is influenced by the Ganges river, which is strongly polluted (Sarkar et al., 2003). This was indeed found (Table 3) as there were significant differences between different areas in the Sundarbans with regard to at least some of the elements studied, and others were probably not significant only because of the large amount of variability between different samples within individual compartments. It is therefore perhaps not surprising that the values reported by Zöckler and Bunting (2006) were lower than ours, since their study was in the east of Bangladesh away from the Ganges and other main sources of pollutants Also, the choice of sites in the present work emphasised areas likely to be polluted because they were near to human activity and hence more accessible. Even so, and allowing for the fact that sediment data is the only comparator medium, the data from the literature suggest that the Sundarbans is not yet as polluted as some other mangroves from the region, such as in Pakistan (e.g. IUCN, 1987).

Clearly, further work is required to confirm and extend the results reported here. The indications of potentially elevated heavy metal concentrations is a matter of concern, and a higher general pollution load is likely to contribute to the increase in top-dying observed in the Sundarbans (Rahman, 2003; Chaffey, et al.,1985; Chowdhuy,1984; Gibson; 1975). A likely mechanism of influence might be that greater concentrations of the trace-metals weaken the resistance of the tree to attack by pathogenic fungi. The relationship between individual trace metals and the amount of top-dying will be explored further in a separate article. It is also worth noting that local residents and those who work in the Sundarbans quite frequently reported health problems, of which problems of the skin were the most common (data from a questionnaire, included in Awal, 2007). It is possible that the high concentration of nickel (Awal, 2007), which can cause skin conditions, is leading to such complaints. Such health issues are therefore also a cause of concern and need further confirmation and elaboration.

\section{Conclusion}

Comparing figures in the table 3.0, it would suggest that about two thirds of the elements have concentrations which are elevated compare to other reference sources in the Sundarbans. This would be consistent with the evidence that heavy metals were having an influence on top-dying intensity (Awal, 2007, 2009, 2014). The elements Pb, Sn, and $\mathrm{Zn}$ were highlighted earlier in this discussion, and although not all of them quite reached statistical significance (Awal, 2007), the positive trend linking two of them to top-dying suggests a likely mechanism of influence, namely that greater concentration of the heavy-metal weaken the resistance of the tree to attack by the pathogenic fungi (Awal, 2007, 2009, 20014). This might well be a process that other elements contribute to as well (Awal, 2007, 2009, 2014), but has not been picked out by the analysis as showing a link because of the variability between samples inherent in the data (Awal, 2007). In this respect, the anomaly of the negative relationship indicated for $\mathrm{Sn}$ is harder to explain (Awal, 2007), but a possible process might be an antagonistic response of $\mathrm{Sn}$ and another element (Awal, 2007), so that when Sn is less abundant the other element can have a stronger (deleterious) effect on the trees (Awal, 2007), thus allowing more topdying to occur (Awal, 2007).

The overall conclusions from the results presented in this section are that the selection of sites has not produced clear statistical differences in the amount of top-dying evident; probably because of the way the data were collected. However, it is believed that there is notable variation between plots and compartments, and certainly this seems to be reflected in the ability of the trees to regenerate. However, the link between top-dying and the size of the trees is not clear, with tree height and diameter not being directly related consistently to amount of top-dying, although moisture content of soil was inversely related. Since the great majority of trees present in all plots is the species Heritiera fomes, this means that the comments above are essentially referring to the response of this species rather than that of any others. So that, the Sundri, by contrast, prefers largely fresh water in which it resembles the mesophytes, but the species is adapted to the wet swampy condition of the Sundarbans by virtue of its leaves having partly xerophytic adaptations and plentiful pneumatophores which help cope with the saline swamps of the Sundarbans. The vegetations need sound ecological balanced to survive but due to deforestations, illicit fellings, hunman destruction are responsible for the heavy metal contaminations in soil, water and vegetation(Awal, 2007, 2009, 2014).

A further point is that variations in soil $\mathrm{pH}$ from site to site (shown to be significant) will also have a marked effect on the bio-availability of some of these heavy metals (Awal, 2007), and thus perhaps influence top-dying (Awal, 2007).We should protect natural resources such as Sundarbans in Bangladesh (Awal, 2009), because the future of Sundarbans is as directly dependent on the health of her wetlands, as is the future flora and fauna. Considering the limitations of the current planning process in Bangladesh, it is possible that within a few short decades, as water tables fall, rivers run dry and lakes shrivel, water-riots will become the order of the day. It may also be the case that wars on the subcontinent will more likely be fought over water than oil. And until uncontrolled development is restricted, the threat of floods and droughts due to loss of mangrove systems will continue to be present (Sahgal, 1991). Coastal lands include some of the most productive of ecosystems with a wide range of natural functions, but are also one of the most threatened habitats because of their vulnerability and attractiveness for 'development'. The first global conservation convention, the Ramsar Convention, focused solely on coastal lands and wetlands, and it has recently been strengthened and elaborated with regard to 
the wise use of all coastal areas such as Sundarbans.

\section{Acknowledgement}

My research work was supported financially by the Peoples' Republic of Bangladesh and the Asian Development Bank (ADB), whom I thank. Particular thanks are due to the ADB head office, Manila for their support and help. I thank sincerely Dr. W.G.H. Hale (Principal Supervisor), University of Bradford, UK, Professor Mike Ashmore (Technical Supervisor), University of York, UK and Dr. P.J. Hogarth for their advice and comments on the work; Dr. Ben Stern and the staff at the Analytical Centre, Bradford, for their help with the ICPMS analyses; Professor Sirajul Hoque, Mustafa (lab Technician)and staff at Dhaka University for providing facilities; and staff of the Forestry Service, Bangladesh Government, for field assistance. Moreover I indebted to my beloved parents Munshi Aowlad Hossain (Father: Teacher and Landlord as well as blossom friend of poor), Mrs. Ashrafunness( Mother: born Literate and Socialist, pious and friend of poor and distress), my venerated forefathers:Abadat Biswas (Mighty-Landlord), GolamRabbani-Biswas(Mighty-Landlord) my esteemed grandfathers (Munshi Bellal Hossain Biswas (LearnedLiterate-Landlord), Md. Ataher (Lawyer and Powerful Jotdar and Landlord), my respected grand-mothers: Rohima Khatun (pious \& friend of poor), and Alimoonnessa (social, pious and friend of poor and distress), Dr. Shajahan Kabir(Nephew), my beloved wife (Dr. Shahanaj Khatun), my beloved son (Munshi Tasneem Redowan), my beloved daughter (Marwa Ashra), my beloved brothers: Munshi Abul Kalam Azad (Officer in BAF), and Munshi Abdus Salam (Program Officer in UNDP), Munshi Abdul Rouf (Businessman), Motiar Rahman (Local Leader and social worker), and my beloved 6 sisters (Layla Anjumand Banu (Chandu), Akter Rashida Banu (Turi), Saleha Pervin (Lili), Azmeri Ferdowsi (Dolly), Jannatul Ferdowsi (Polly) and my beloved youngest sister Bedowra Ferdowsi (Jolly), Chandona, Sultana, Rono, Chapa, Loti, Urfa, Alta, Joytoon, my respected only uncle Munshi Abdur Razzak (Teacher and Jotder as well as blossom Friend of poor people),NoorJahan (unty), Kolimuddin Biswas(Aunt), my venerated maternal uncles: Anowarul Azim (Director of Family Planning), Amirul Azim (First Class-Magistrate and UNO), Aftabul Azim (Banker), Azizul Azim (Influential Leader and Govt.-Officer in Land Department), Anisul Azim (Social Leader and influential-Businessman), Aminul Azim(Dramatist), my respected Khalas (Khuki, Bulbul), as well as all family members for their inspiration and help.

\section{References}

[1] Awal, M.A. (2007). Analysis of possible environmental factors causing top-dying in mangrove forest trees in the Sundarbans in Bangladesh. $\mathrm{PhD}$ thesis, University of Bradford.
[2] Awal, M.A., Hale, W.H.G. \& Stern, B. (2009). Trace element concentrations in mangrove sediments in the Sundarbans, Bangladesh. Marine Pollution Bulletin, 58(12), 1944-1948.

[3] Awal, M.A. (2014). "Correlation between the chemical composition of the surface sediment and water in the mangrove forest of the Sundarbans, Bangladesh, and the regeneration, growth and dieback of the forest trees and people health"..Journal of Science Innovation; 2014. 2(2): pp.11-21.Science Publishing Group, USA; May 20th, 2014(2):11-21;doi: 10.11648/j/si.20140202.11.

[4] Asian Development Bank, 1993-95. Main Plan-1993/2012. Vol.1. Forestry Master Plan. Asian Development Bank, Manila, Philippines.

[5] Anonymous, 1986. Mangroves in India: Status Report, Government of India, Ministry of Environment and Forests, New Delhi, 150 pp.

[6] Anonymous, 1986. Sundri trees fast reducing. The Bangladesh Observer, $1^{\text {st }}$. December, 1986.

[7] Bangladesh Bureau of Statistics, 2006. Statistical Yearbook of Bangladesh, Statistics Division. Ministry of Planning. Dhaka, Bangladesh.

[8] Bari, A. 1993. Afforestation and the nutrient sink. Assistance to Fisheries Research Institute. Mymensingh. BGD / 89 / 012, Field Document-3.

[9] Burns, K.A; S. D. Garrity, and S.C. Levings. 1993. How many years until mangrove ecosystems recover from catastrophic spills? Marine Pollution Bulletin 26 (5): 239248.

[10] Chaffey, D. R; Miller, F.R; Sandom, J. H. 1985. A forest inventory of the Sundarbans, Bangladesh, Main report, Project Report No.140, 196 pp; Overseas Development Administration, London, U.K:195-196.

[11] Chantarasri, S. 1994. Integrated Resource Development of the Sundarban, Fisheries Resources Mangagement for the Sundarban, UNDP / FAO, BGD / 84 / 056, Khulna, Bangladeshp: 170-172.

[12] Chowdhury, A.M. 1984. Integrated Development of the Sundarbans, Bangladesh: Silvicultural Aspects of the Sundarbans. FAO Report No / TCP/ BGD/ 2309 (Mf), W / R003.

[13] Chowdhury, M. I. 1984. Morphological, hydrological and ecological aspects of the Sundarbans. FAO report N0. FO: TCP/BGD/2309(Mf) W /R0027, 32 P.

[14] Christensen, B. 1984. Integrated development of the Sundarbans, Bangladesh: Ecological aspects of the Sundarbans. Reported prepared for the Government of Bangladesh. FAO report no. FO: TCP/ BGD/2309(MF) W/ R0030.

[15] Faizuddin, M. 2003. Research on the Top Dying of Sundri in Bangladesh: 43, Mangrove Silviculture Division, Bangladesh Forest Research Institute, Khulna, Bangldesh.

[16] Faizuddin, M. and Islam, S.A. 2003. Generated Technology and Usable Information of the Mangrove Silviculture. Mangrove Silviculture Division, Bangladesh Forest Research Institute, Khulna, p. 17. 
[17] FAO, 1993. Forest resources assessment 1990: Tropical countries. FAO Forestry Paper. 112, Rome, 98-102p.

[18] FAO, 1994. Review of the state of world marine fisheries resources. FAO Fisheries resources. FAO Fisheries Technical Approach Paper 335:143.

[19] Gibson, I.A.S. 1975. Reports on a visit to the People's Republic of Bangladesh, 28 February to 1 April 1975.Unpublished Report, ODA, London, 28pp.

[20] Government of Bangladesh, (1993). Forestry Master Plan: Executive Summary. Asian Development Bank, UNDP/FAOBGD/88/025, Forest Department, Government of Bangladesh, Dhaka.31p.

[21] Government of Bangladesh, (2006).Mosaic of Bangladesh; 2006; External Publicity Wing; Ministry of Foreign Affairs; Government of the People's Republic of Bangladesh; p:1145

[22] Hambrey, J. 1999. Mangrove, Fisheries and Economic. Aquaculture and Aquatic Resource Management Program. Asian Institute of Technology. Thailand: 1-4.

[23] Harris, L. D. (1984). The Fragmented Forest: Island Biogeographic Theory and the Preservation of Biotic Diversity. Chicago: University of Chicago Press.

[24] Hussain, Z. and Karim, A. (1994). Introduction. In: Mangroves of the Sundarbans. Volume 2: Bangladesh, Z. Hussain and G. Acharya (Eds.) IUCN. Bankok, Thailand. !$18 \mathrm{pp}$.

[25] Islam, M. A.1993. Some Relevant Information about Sundarban. Sundarbans Forest Division, Khulna, Bangladesh, p. 21.
[26] Mukharjee, A. K. 1975. The Sundarbans of India and its biota. Journal of Bombay Natural History Society, 72 (1):120 .

[27] Rahman, M.A. 2003. Genetic Approach to mitigate the top Dying Problem of Heritiera fomes in the Mangrove Forests, Khulna University, Bangladesh, 87pp.

[28] Rahman, M.A. 2003. Mid-term Report on Top Dying of Sundri (Heritiera fomes) and Its Management in the Sundarbans Biodiversity Conservation Project, Khulna.109pp.

[29] Seidensticker, J. Hai; A. 1983. The Sundarbans wildlife management plan: conservation in the Bangladesh (cited in Chaffey et al., 1985), Bangladesh.

[30] Tiner, R. W; J R. (1984). Wetlands of the United States: Current Status and Recent Trends. Newton Corner, Massachusetts: U.S. Fish and Wildlife Service, Habitat Resources.

[31] UN-ESCAP, 1987. Final Report: Volume 2. Coastal environment management plan for Bangladesh. Bangkok, Thailand.

[32] UN-ESCAP, 1988. Coastal environment management plan for Bangladesh. Bangkok, Thailand: 7-34.

[33] WHO, 1981. Resistance of Disease vectors to pesticides. World Health Organisation, Chronicle, 35, 143. 